\title{
DETEKSI FORMALIN DAN LOGAM BERAT PADA IKAN SEGAR DI PASAR TRADISIONAL KOTA KUPANG
}

\author{
A. T. Lema ${ }^{*}$ dan J. M. Jacob ${ }^{2}$ \\ ${ }^{1}$ Program Studi Teknologi Pakan Ternak, Jurusan Peternakan, Politeknik Pertaninan Negeri \\ Kupang, Kupang, Indonesia \\ ${ }^{2}$ Program Studi Kesehatan Hewan, Jurusan Peternakan, Politeknik Pertaninan Negeri Kupang, \\ Kupang, Indonesia \\ *Email:abner_t.lemal@yahoo.com
}

\begin{abstract}
ABSTRAK
Dewasa ini penggunaan formalin sebagai pengawet pada ikan sering dijumpai di masyarakat. Selain itu, konsumsi produk olahan ikan segar yang mengandung logam berat akan berpotensi menyebabkan timbulnya berbagai penyakit baik jangka pendek maupun jangka panjang. Penelitian ini bertujuan untuk mengkaji perilaku masyarakat, mendeteksi adanya formalin serta menganalisis kadar $\mathrm{Pb}, \mathrm{Cd}$ dan $\mathrm{Hg}$ pada ikan Belang Kuning, Tongkol dan Kembung. Metode deteksi kualitatif formalin menggunakan pereaksi Schiff berdasarkan reaksi perubahan warna sampel menjadi merah-keungunan, sedangkan secara kuantitatif menggunakan metode Spektrofotometri berdasarkan reaksi antara formaldehid dengan pereaksi Nash yang menghasilkansenyawa kompleksberwarna kuning. Hasil penelitian menunjukkan bahwa sekitar 50\% masyarakat kota Kupang sebagai belum mengetahui tentang formalin dan ciri-ciri ikan yang berformalin. Uji kualitatif pada 9 sampel memberikan hasil positif formalin pada 2 sampel ikan, sedangkan 7 sampel lainnya memberikan hasil negatif. Sedangkan uji kuantitatif menunjukkan kadar formalin terbesar pada sampel ikan di pasar Oesapa sebesar 3,36 ppm pada ikan tongkol dan 1,26 ppm pada ikan kembung. Kandungan logam berat tertinggi yaitu Hg dengan range konsentrasi 1,00-1,60 ppm untuk semua jenis ikan dari 3 sumber pasar.
\end{abstract}

Kata kunci: formalin, logam berat, ikan segar, pasar, Kota Kupang

\section{ABSTRACT}

Nowadays, the use of formalin as a preservative in fish is often found in society. Besides, the consumption of fresh fish products containing heavy metals will potentially cause various diseases both short and long-term. The aims of this study were to assess the knowledge of society about formalin, detect the presence of formalin, and analyze the heavy metal content of $\mathrm{Pb}, \mathrm{Cd}$, and $\mathrm{Hg}$ in Yellow striped fish, Tuna and Mackerel fish. The qualitative detection was done using Schiff reagents, while the quantitative detection was done by using the Spectrophotometry based on the reaction of formaldehyde and Nash reagents. The results showed that 50 percent of society did not know about the use of formaldehyde and its characteristics in fish. The Qualitative testing on 9 samples found that 2 samples contained positive formalin, while 7 samples were negative. The quantitative test showed that the highest formalin content was found in Tuna and Mackerel fish with concentration of $3.36 \mathrm{ppm}$, and $1.26 \mathrm{ppm}$, respectively. Also, mercury was found as the highest concentration in fish roughly 1 to $1.60 \mathrm{ppm}$ for those samples from three different markets.

Keywords: formalin, heavy metal, fresh fish, market, Kupang city

\section{PENDAHULUAN}

Salah satu faktor yang mempengaruhi kualitas sumber daya manusia yaitu kualitas pangan yang dikonsumsi. Penggunaan pengawet pada bahan makanan sampai saat ini masih banyak dijumpai. Dewasi ini, penggunaan Formaldehida (FA) sebagai pengawet banyak ditemukan pada bahan makanan dengan tujuan untuk menjaga kesegaran makanan, dan waktu penyimpanan yang lama. Asupan FA yang berlebihan akan menyebabkan gangguan pada sistem syaraf, sistem pernapasan dan gangguan pencernaan (Adriani \& Karim, 2019).

Jenis pengawet yang sedang ramai dibicarakan di kalangan masyarakat yaitu penggunaan formalin sebagai pengawet bahan makanan. Penggunaan bahan kimia berbahaya 
dalam penanganan dan pengolahan ikan seperti formalin, boraks, zat pewarna, antiseptik, antibiotik semakin marak karena peredaran bahan kimia berbahaya tidak terkontrol dengan baik, diperoleh dengan harga murah dan mudah didapat(Tatuh, 2016).Ikan merupakan sumber protein yang murah dibandingkan dengan daging dan mengandung komposisi nutrisi yang lengkap termasuk asam amino esensial yang tidak dapat dihasilkan di dalam tubuh (Adriani \& Karim, 2019; Immaculate \& Jamila, 2018).

Nusa Tenggara Timur merupakan salah satu wilayah kepulauan yang sebagaian besar penduduknya memiliki mata pencaharian sebagai nelayan. Situasi yang ditemukan di lapangan yaitu adanya distribusi ikan segar antar pulau yang ada di NTT ke kota Kupang membutuhkan beberapa hari transportasi laut. Distribusi ikan antar pulau ini membutuhkan waktu 2 sampai 3 hari untuk sampai ke kota Kupang dan diduga akan mengalami penurunan kualitas akibat kontaminasi protozoa, jamur, cacing, dan bakteri. Oleh sebab itu, muncul upaya pengawetan untuk menjaga kesegaran dan keawetan ikan menggunakan es batu bahkan ada oknum yang menggunakan formalin.

Organisasi Kesehatan Dunia (WHO) memperkirakan formalin berada dalam kisaran 1,5-14 $\mathrm{mg} /$ hari (rata-rata $7,75 \mathrm{mg} / \mathrm{hari}$ ) untuk rata-rata orang dewasa, dan menurut Badan Keamanan Pangan Eropa (EFSA), pajanan oral harian formalin dari total diet tidak boleh melebihi $100 \mathrm{mg} /$ hari. Ketika dicerna formalin memberikan efek sakit kepala, tenggorokan panas dan kesulitan bernapas. Jika dikonsumsi pada konsentrasi yang lebih tinggi, formalin dapat menyebabkan kerusakan pada saluran pencernaan, ginjal, hati dan paru-paru, dan dapat menyebabkan kanker. Badan Internasional untuk Penelitian Kanker (IARC) telah mengklasifikasikan formaldehida sebagai karsinogen Grup 1 (Das, Jana, Dhanabalan, \& Xavier, 2018; Nowshad, Islam, \& Khan, 2018).

Logam berat $\mathrm{Pb}, \mathrm{Cd}$ dan $\mathrm{Hg}$ merupakan sumber pencemar yang menjadi pusat perhatian beberapa negara. Konsumsi produk olahan ikan atau ikan Segar akan berpotensi menyebabkan timbulnya berbagai penyakit baik jangka pendek maupun jangka panjang. Termasuk cacat mental, kelainan syaraf, gangguan pernapasan dan ganggguan pencernaan (Aji \& Indriati, 2008). Logam berat masuk ke dalam jaringan tubuh ikan melalui beberapa cara, yaitu saluran pencernaan, saluran pernapasan, dan penetrasi melalui kulit. Adanya akumulasi logam berat seperti $\mathrm{Pb}, \mathrm{Cd}$ dan $\mathrm{Hg}$ pada ikan akan mempengaruhi kualitas ikan. Banyaknya logam berat yang terserap pada ikan tergantung pada senyawa dan konsentrasi polutan, aktivitas mikroorganisme, tekstur sedimen, jenis dan unsur ikan yang hidup di lingkungan tersebut. Hasil penelitian Harteman (Harteman, et.all, 2008) memberikan gambaran bahwa kemampuan akumulasi logam berat pada ikan berturut-turut yaitu $\mathrm{Hg}>\mathrm{Cd}>\mathrm{Pb}$ pada organ ikan.

Penelitian ini perlu dilakukan sehingga dapat menjawab permasalahan di masyarakat terkait isu pangan yang mengandung formalin dan juga peneliti menemukan beberapa produk ikan di salah satu pasar tradisional yang mengindikasikan adanya formalin pada produk ikan.

\section{MATERI DAN METODE}

\section{Bahan}

Sampel yang digunakan yaitu sampel ikan belang kuning, ikan tongkol, ikan kembung. Bahan kimia yang digunakan memiliki grade pro analyse (pa) yaitu: formalin $37 \%$, serbuk fuchsin, $\mathrm{NaHSO}_{3}, \mathrm{HCl}$ pekat, $\mathrm{H}_{3} \mathrm{PO}_{4}$, asetil aseton, asam asetat glasial, amonium asetat, $\mathrm{HNO}_{3}$ pekat, $\mathrm{H}_{2} \mathrm{O}_{2}$ pekat dan aquades.

\section{Alat}

Alat yang digunakan yaitu neraca analitik, oven, labu takar, lumpang porselin, seperangkat alat destilasi Spektrofotometer UV-Vis (Cecil 2021), Spektrofotometer Serapan Atom (merck Agilent Technologies, serie 280 FSAA), mikropipet dan peralatan gelas lainnya

\section{Metode Penelitian \\ Survey Pasar dan Sampling Ikan}

Survei pasar dilakukan di tiga pasar tradisional yaitu pasar Oesapa, pasar Inpres Naikoten dan pasar Oeba. Pada tahapan ini dilakukan wawancara terhadap 30 pembeli (responden) untuk mengetahui perilaku dan pengetahuan masyarakat tentang formalin. Survei dilakukan menggunakan kuisioner yang fokus mengenai perilaku dan pengetahuan masyarakat tentang formalin dan penggunaanya.

\section{Preparasi Sampel}

Untuk analisis formalin secara kualitatif dan kuantitatif dilakukan preparasi sampel ikan sebagai berikut: sampel ikan segar dipotong ukuran $1 \times 1 \times 1 \mathrm{~cm}$ dan ditimbang sebanyak 5 
gram. Sampel dihaluskan dan didestilasi pada suhu rendah $\left(60-80{ }^{\circ} \mathrm{C}\right)$. Penambahan asam sulfat bertujuan untuk mendestruksi strukur daging pada ikan dan memisahkan ekstrak yang mengandung bahan pengawet. Proses destilasi dilakukan selama 1 jam untuk masing-masing sampel. Analisis kadar logam berat dilakukan dengan preparasi sampel ikan sebagai berikut: sampel ikan dikeringkan pada oven dengan suhu $100^{\circ} \mathrm{C}$. Kemudian sampel didestruksi dalam kondisi asam dengan pelarut $\mathrm{H}_{2} \mathrm{O}_{2}: \mathrm{HNO}_{3}(2: 1)$. Hasil destruksi berupa larutan kental berwarna cokelat yang kemudian diencerkan dengan 100 $\mathrm{mL}$ aquades dan diukur kadar logam $\mathrm{Pb}, \mathrm{Cd}$ dan $\mathrm{Hg}$ menggunakan AAS (Atomic Absorption Spectrophotometry).

\section{Analisis kualitatif dan kuantitatif formalin pada ikan}

Filtrat hasil preparasi dari masing-masing sampel diambil sebanyak $2 \mathrm{~mL}$, dimasukkan dalam tabung reaksi dan ditambahkan dengan 5 tetes pereaksi Schiff lalu diamati perubahan warna yang terjadi. Hasil positif adanya formalin ditunjukkan oleh terbentuknya warna merah keunguan.

Uji Kuantitatif kadar formalin: analisis kuantitatif dengan menggunakan pereaksi Nash. Masing-masing filtrat yang diperoleh dari sampel dipipet $5 \mathrm{~mL}$ ke dalam labu ukur $10 \mathrm{~mL}$. Volumenya dicukupkan dengan menggunakan pereaksi Nash sampai tanda batas, larutan dipanaskan selama 30 menit pada suhu $37^{\circ} \mathrm{C}$ lalu dibiarkan dingin pada suhu kamar selama 30 menit. Serapan larutan diukur menggunakan spektrofotometer UV-Vis pada gelombang maksimum. Penentuan konsentrasi formalin menggunakan kurva kalibrasi dengan persamaan $Y=a x+b$ Pengukuran absorbansi masingmasing sampel diulangi sebanyak 3 kali.

\section{Analisis logam berat pada sampel ikan}

Sampel ikan dikeringkan menggunakan oven dengan suhu $100^{\circ} \mathrm{C}$. Kemudian didestruksi dalam kondisi asam $\mathrm{H}_{2} \mathrm{O}_{2}: \mathrm{HNO}_{3}(1: 2)$. Hasil destruksi berupa larutan kental berwarna cokelat yang kemudian diecerkan pada labu takar 100 $\mathrm{mL}$ dan diukur kadar logam $\mathrm{Pb}, \mathrm{Cd}$ dan $\mathrm{Hg}$ menggunakan AAS.

\section{HASIL DAN PEMBAHASAN}

Survei pasar dilakukan pada 3 pasar tradisional yang ada di kota Kupang yaitu pasar
Oesapa, pasar Inpres Naikoten dan pasar Oeba. Ketiga pasar ini merupakan pasar tradisional yang memiliki aktivitas yang padat dan di pasar-pasar ini juga terdapat berbagai jenis komoditi. Untuk melihat seberapa besar minat pembeli ikan dan pengetahuan pembeli terhadap isu formalin pada ikan maka dilakukan kajian menggunakan kuisioner. Setiap pasar diambil 10 orang pembeli sebagai responden dan langsung diwawancarai oleh mahasiswa sebagai tim dalam penelitian ini. Berdasarkan hasil wawancara terhadap 30 orang responden atau pembeli maka diperoleh $50 \%$ responden sudah mengetahui dan paham tentang formalin dan bahayanya bagi kesehatan namun mereka belum mengetahui secara spesifik ciri-ciri ikan segar yang berformalin. Sedangkan 50\% pembeli lainnya tidak mengetahui sama sekali bahwa formalin dan ciri-ciri formalin pada produk ikan segar.

Hasil wawancara dengan sebagian nelayan dan pedangan ikan bahwa hampir semua jenis ikan besar didatangkan dari pulau Flores dan Alor dalam jangka waktu 2-3 hari. Adapun wawancara terhadap nelayan dan penjual ikan mengalami sedikit keterbatasan karena secara psikologis, mereka merasa terintimidasi dengan pertanyaan-pertanyaan yang mengarah kepada penggunaan bahan kimia berbahaya. Hasil wawancara dengan penjual dan nelayan di lokasi pasar memberikan gambaran bahwa ikan segar yang tersebar di tiga pasar tradisional di kota Kupang berasal dari sumber yang sama yaitu kepulauan Flores dan kepulauan Alor.

\section{Penentuan formalin secara kualitatif dan kuantitatif}

Uji kualitatif adanya formaldehida atau formalin menggunakan pereaksi Schiff. Pereaksi ini bereaksi dengan formalin membentuk senyawa kompleks berwarna merah-keunguan. Berdasarkan hasil analisis 9 sampel dari 3 pasar tradisional yang berbeda, ternyata secara kualitatif tidak terjadi perubahan warna dari kuning menjadi merah-keunguan. Hal ini mengindikasikan bahwa metode kualitatif tidak dapat mendeteksi formaldehida dalam konsentrasi yang kecil. Diduga dalam 9 sampel ikan tersebut memiliki kandungan formalin dalam jumlah kecil sehingga belum terdeteksi dengan secara kualitatif. 
Tabel 1. Hasil uji kualitatif formalin menggunakan pereaksi Schiff

\begin{tabular}{clll}
\hline Sampel & Sumber Pasar & $\begin{array}{c}\text { Perubahan } \\
\text { warna }\end{array}$ & $\begin{array}{l}\text { Hasil } \\
\text { Uji }\end{array}$ \\
\hline \multirow{2}{*}{ Ikan Belang } & Pasar Oesapa & Tetap kuning & Negatif \\
Kuning & PasarNaikoten & Tetap kuning & Negatif \\
& Pasar Oeba & Tetap kuning & Negatif \\
\hline \multirow{2}{*}{ Ikan } & Pasar Oesapa & Merah muda & Positif \\
Tongkol & PasarNaikoten & Tetap kuning & Negatif \\
& Pasar Oeba & Tetap kuning & Negatif \\
\hline \multirow{2}{*}{ Ikan } & Pasar Oesapa & Merah muda & Positif \\
Kembung & Pasar & & \\
& Naikoten & Tetap kuning & Negatif \\
& Pasar Oeba & Tetap kuning & Negatif \\
\hline
\end{tabular}

Berdasarkan hasil deteksi kualitatif pada Tabel 1, menunjukkan bahwa dari 9 sampel, ditemukan 2 sampel positif mengandung formalinyang ditandai dengan perubahan warna kuning menjadi merah muda, sedangkan 7 sampel lainnya dinyatakan negatif. Pereaksi Schiff yang digunakan ini merupakan campuran 0,2 gram fuchsin, $2 \mathrm{~mL} \mathrm{NaHSO}$ dan $5 \mathrm{~mL} \mathrm{HCl}$ pekat. Hasil pra-penelitian menggunakan sampel sintetis formalin menunjukkan bahwa pereaksi Schiff sangat sensitif atau memberikan perubahan warna pada konsentrasi formalin atas $1 \mathrm{ppm}$. Hal ini diperkuat pada tahapan penentuan limit deteksi metode Spektrofotometri untuk penentuan formalin memberikan LoD sebesar 0,01 ppm. Penentuan LoD ini dilakukan dengan mengukur absorbansi dari 10 larutan blanko (tanpa sampel).

Penelitian yang dilakukan oleh Adriani(Adriani \& Karim, 2019) memberikan hasil deteksi formalin yang negatif pada sampel ikan menggunakan pereaksi Schryver. Hal ini diduga karena kandungan formalin yang sangat kecil sulit terdeteksi menggunakan uji kualitatif.

Tahapan uji formalin secara spektrofotometri yaitu menentukan panjang gelombang maksimum yang digunakan pada setiap tahap pengukuran absorbansi sampel. Panjang gelombang maksimum ini memberikan serapan yang tinggi sehingga akan mengurangi terjadinya kesalahan dalam pengukuran absorbansi (Lema, et.all, 2014). Pereaksi Nash memberikan perubahan warna sampel menjadi kuning sehingga penentuan panjang gelombang diukur dalamrange panjang gelombang 400-500 $\mathrm{nm}$. Hasil penentuan panjang gelombang diperoleh serapan tertinggi $417 \mathrm{~nm}$ sebagai panjang gelombang maksimum.

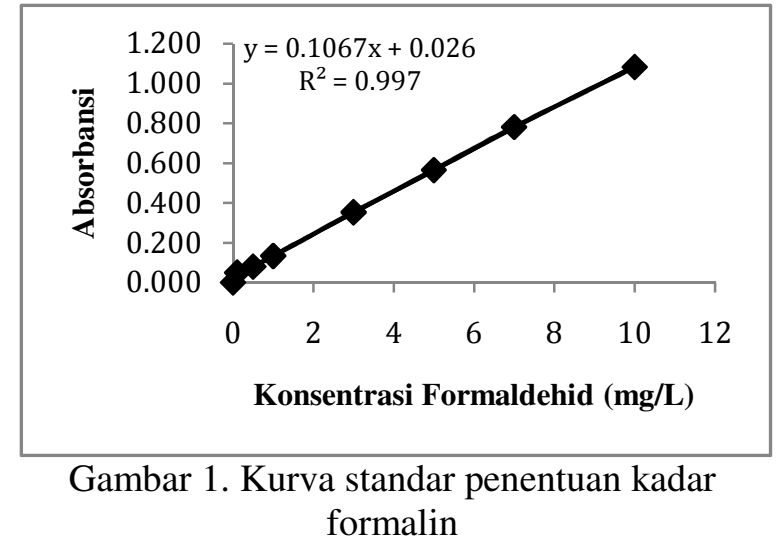

Penetuan konsentrasi formalin menggunakan kurva kalibrasi yaitu mengukur absorbansi sederatan larutan standar formalin untuk memperoleh persamaan regresi linear $\boldsymbol{Y}=\boldsymbol{a x}+$ b. Hasil pembuatan kurva kalibrasi diperoleh persamaan $\boldsymbol{Y}=\mathbf{0 , 1 0 6 7} \boldsymbol{x}+\mathbf{0 , 0 2 6}$ dengan nilai linearitas $\left(r^{2}\right)=0,997$. Jika nilai $r^{2}$ mendekati 1 , maka kurva semakin linear yang menunjukkan bahwa ada hubungan yang linear antara konsentrasi formaldehida terhadap nilai absorbasi senyawa kompleks tersebut. Hasil penentuan kodar formalin pada 9 sampel ikan ditunjukkan pada Tabel 2.

Tabel 2. Kandungan formalin pada ikan segardi 3 lokasi pasar tradisional

\begin{tabular}{clc}
\hline Sampel & Sumber Pasar & $\begin{array}{c}\text { Rerata Kadar } \\
\text { Formalin } \\
(\mathrm{mg} / \mathrm{L})\end{array}$ \\
\hline Ikan & Pasar Oesapa & 0,011 \\
Belang & Pasar Naikoten & 0,545 \\
Kuning & Pasar Oeba & 0,414 \\
\hline \multirow{2}{*}{ Ikan } & Pasar Oesapa & 3,360 \\
Tongkol & Pasar Naikoten & 0,300 \\
& Pasar Oeba & 0,517 \\
\hline \multirow{2}{*}{ Ikan } & Pasar Oesapa & 1,260 \\
Kembung & Pasar Naikoten & 0,030 \\
& Pasar Oeba & 0,021 \\
\hline
\end{tabular}

Berdasarkan hasil penentuan formalin secara spektrofotometri menunjukkan adanya kandungan formalin pada beberapa sampel ikan. Kadar formalin yang terbesar ditemukan pada sampel ikan asal pasar Oesapa dengan kandungan formalin sebesar 3,36 ppm pada ikan tongkol dan 1,26 ppm pada ikan kembung. Sedangkan di pasar Inpres Naikoten ditemukan kandungan formalin pada ikan belang kuning sebesar 0,54 ppm dan 0,414 ppm di pasar Oeba. Kadar formalin terendah terdapat pada ikan kembung di pasar Oeba dan pasar Inpres Naikoten dengan 
range kandungan formalin 0,01-0,03 $\mathrm{ppm}$. Penentuan formalin secara spektrofotometri menggunakan pereaksi Nash juga dilaporkan oleh Adriani (Adriani \& Karim, 2019) pada beberapa pasar di kota Makasar dan menunjukkan kandungan formalin pada ikan sebesar 0,0043$0,2877 \mathrm{ppm}$. Berdasarkan IPCS, batas toleransi kadar formalin pada ikan untuk orang dewasa yaitu 1,5-14 mg/hari. Bila dibandingkan dengan hasil deteksi formalin pada ikan di 3 pasar tradisional kota Kupang, maka kadar tersebut masih berada dalam ambang batas normal yang ditentukan. Namun perlu ada upaya monitoring secara regular oleh Dinas Kesehatan Kota Kupang atau BPOM Kupang.

\section{Penentuan kadar logam berat}

Logam berat yang cenderung membahayakan kesehatan yaitu logam $\mathrm{Pb}, \mathrm{Cd}$ dan Hg. Ketiga jenis logam berat ini terakumulasi pada ikan berdasarkan jenis ikan dan tingkat kedalaman laut. Hasil analisis kandungan logam $\mathrm{Pb}, \mathrm{Cd}$ dan $\mathrm{Hg}$ menggunakan Spektrofotometer Serapan Atom dapat dilihat pada Tabel 3.

Tabel 3. Kandungan logam berat pada ikan segar di 3 lokasi pasar tradisional

\begin{tabular}{lllll}
\hline \multirow{2}{*}{ Jenis Sampel } & \multirow{2}{*}{ Sumber Pasar } & \multicolumn{3}{c}{ Konsentrasi Logam } \\
\cline { 3 - 5 } & & $\mathrm{Pb}$ & $\mathrm{Cd}$ & $\mathrm{Hg}$ \\
\hline \multirow{3}{*}{$\begin{array}{l}\text { Ikan Belang } \\
\text { Kuning }\end{array}$} & Pasar Oesapa & 0,12 & 0,010 & 1,12 \\
& Pasar & & & \\
& Naikoten & 0,15 & 0,018 & 1,45 \\
& Pasar Oeba & 0,075 & 0,024 & 1,13 \\
\hline \multirow{3}{*}{ Ikan } & Pasar Oesapa & 0,012 & 0,015 & 1,60 \\
Tongkol & Pasar & & & \\
& Naikoten & 0,091 & 0,028 & 1,42 \\
& Pasar Oeba & 0,11 & 0,020 & 1,07 \\
\hline \multirow{3}{*}{ Ikan } & Pasar Oesapa & 0,17 & 0,013 & 1,50 \\
Kembung & Pasar & & & \\
& Naikoten & 0,09 & 0,022 & 1,10 \\
& Pasar Oeba & 0,10 & 0,019 & 1,00 \\
\hline
\end{tabular}

Analisis kadar logam pada ikan Belang Kuning, Ikan Tongkol dan ikan Kembung mengandung logam $\mathrm{Pb}, \mathrm{Cd}$ dan $\mathrm{Hg}$. Jika dilihat dari ketiga logam berat tersebut, merkuri $(\mathrm{Hg})$ memiliki kadar tertinggi yaitu dengan range konsentrasi 1,00-1,60 ppm untuk 3 sumber pasar yang berbeda. Sedangkan kandungan logam $\mathrm{Cd}$ berkisar antara 0,01-0,028 ppm dan Pb berkisar antara 0,09-0,17 ppm untuk jenis ketiga jenis ikan dari sumber yang berbeda. Tingginya kandungan merkuri dalam ketiga sampel ikan ini diduga karenaadanya proses akumulasi logam berat pada organ ikan.Berdasarkan Peraturan
Badan Pengawas Obat dan Makanan (BPOM)Nomor 5 tahun 2018tentang batas maksimum cemaran logam berat dalam pangan olahan, ditetapkan batas toleransi logam berat pada ikan yaitu $\mathrm{Pb} \mathrm{0,2} \mathrm{mg/Kg,} \mathrm{Cd} \mathrm{0,1} \mathrm{mg/Kg} \mathrm{dan}$ $\mathrm{Hg}$ sebesar 0,5 mg/Kg(BPOM, 2018). Hal ini mengindikasikan bahwa logam berat $\mathrm{Pb}$ dan $\mathrm{Cd}$ masih berada dalam ambang batas dalam pangan. Sedangkan ketiga jenis ikan dari 3 jenis pasar tercemar logam merkuri karena melebihi ambang batas maksimum $(0,5 \mathrm{mg} / \mathrm{Kg})$.

Penelitian yang dilakukan oleh Harteman (Harteman et al., 2008) yaitu urutan kemampuan ikan air tawar dalam menyerap dan mengakumulasi logam berat yaitu $\mathrm{Hg}>\mathrm{Cd}>\mathrm{Pb}$. Sedangkan hasil penelitian pada ikan laut menunjukkan bahwa akumulasi logam $\mathrm{Hg}>\mathrm{Pb}>$ Cd. Hal ini disebabkan oleh adanya perbedaan densitas air, polutan, mikroorganisme dan sedimentasi jenis logam. Proses akumulasi merkuri di dalam tubuh biota air lebih tinggi karena kecepatan pengambilan merkuri oleh hewan air lebih cepat dibanding dengan proses ekskresi, karena merkuri memiliki waktu sampai beberapa ratus hari di tubuh biota air, sehingga logam ini menjadi terakumulasi dan konsentrasinya lebihbesar dibanding logam lainnya.

\section{SIMPULAN}

Kadar formalin tertinggi ditemukan pada sampel ikan asal pasar Oesapa sebesar 3,36 ppm pada ikan tongkol dan 1,26 ppm pada ikan kembung. Sedangkan di pasar Naikoten ditemukan kandungan formalin pada ikan belang kuning sebesar 0,54 ppm dan 0,414 ppm di pasar Oeba. Namun range kadar formalin ini masih diperbolehkan karena tidak melebihi ambang batas normal formalin (1,5-14 ppm). Kandungan logam berat tertinggi yaitu $\mathrm{Hg}$ dengan range konsentrasi 1,00-1,60 ppm pada semua jenis ikan dari 3 sumber pasar tradisional yang berbeda.Sesuai denganPeraturan Badan Pengawas Obat dan MakananNomor 5 tahun 2018, maka ketiga jenis ikan ini tercemar logam berat merkuri (batas maksimum $0,5 \mathrm{ppm}$ ).

\section{DAFTAR PUSTAKA}

Adriani, A., \& Karim, A. 2019. Analysis of Formaldehyde Preservatives in Wet Anchovy (Stolephorus sp.) from Traditional Markets in Makassar City, South Sulawesi. Jurnal Akta Kimia Indonesia (Indonesia 
Chimica Acta). 11(1): 1-10.

Aji, N., \& Indriati, N. 2008. Residu Logam Berat pada Ikan dan Kualitas Lingkungan Perairan Muara Sungai Barito Kalimantan Selatan. Jurnal Pascapanen dan Bioteknologi Kelautan Dan Perikanan. 3(2): 147-155.

BPOM. 2018. Peraturan Badan Pengawas Obat dan Makanan No 5 Tahun 2018 Tentang Batas Maksimum Cemaran Logam Berat dalam Pangan Olahan. 1-8. Jakarta.

Das, U. N., Jana, P., Dhanabalan, V., \& Xavier, K. A. M. 2018. Detection of Formaldehyde Content in Selected Fishes from Three Different Retail Markets at Mumbai. Int. J. Curr. Microbiol. App. Sci. 7(11): 23162322.

Harteman, E., Soedharma, D., Winarto, A., \& Sanusi, H. S. 2008. Deteksi Logam Berat pada Perairan, Sedimen dan Sirip Ikan Badukang (Anus caelatus han a. Maculatus) di Muara Sungai Kahayan dan Sungai
Katingan, Kalimantan Tengah. Berita biologi. 9(3): 275-283.

Immaculate, J., \& Jamila, P. 2018. Quality Characteristics Including Formaldehyde Content in Selected Sea Foods of Tuticorin, Southeast Coast of India. International Food Research Journal. 25(1).

Lema, A. T., Sulistyarti, H., \& Atikah, A. 2014. Development of Spectrophotometric Methods for Iodide Determination Using Hydrogen Peroxide (H2O2) as Oxidizing. Natural B, 2(4): 309-316.

Nowshad, F., Islam, M. N., \& Khan, M. S. 2018. Concentration and Formation Behavior of Naturally Occurring Formaldehyde in Foods. Agriculture \& Food Security. 7(1):17.

Tatuh, H. A. 2016. Analisis Kandungan Formalin pada Berbagai Jenis Ikan di Kota Manado. Pharmacon. 5(4). 